\title{
大型ティスプレイ(110インチ)を用いた作業 における注視角度の比較
}

\author{
○小嶺憲国(産業医科大学人間工学)、戸上英憲(生体情報分析室)、三宅晋司(産業保健学部) \\ 高橋雄三(人間工学)、橋本正浩(生体情報分析室)、神代雅晴(人間工学)、田中圭一郎(日立製作所) \\ Comparison of two viewing angles during vigilance task with large-sized display \\ Norikuni Komine (Dept. of Ergonomics (1), UOEH), Hidenori Togami (Analytical Laboratory of \\ Human Information (2)), Shinji Miyake (School of Health Sciences), Yuzo Takahashi ((1)), \\ Masahiro Hashimoto ((2)), Masaharu Kumashiro ((1)), Keiichiro Tanaka (Hitachi Ltd.)
}

\section{1.はじめに}

近年、100インチ以上の大型ディスプレイが 登場し各種プラント・交通監視, 教育, 情報提 供に利用されている。大型ディスプレイを用 いた作業では、その大きさ故に作業者は水平 より上方を注視することが多い(見上げ姿勢)。

反して、従来型VDTのガイドラインでは俯 角姿勢でディスプレイを見ることが蔦められ ている。従来型VDTでの研究成果よりディス プレイ位置が高くなると、眼球露出面積の増 加 ${ }^{1}$, 涙液分泌量の低下 ${ }^{2)}$, 体幹の後傾 ${ }^{1)}$, 澒部角 度の変化などが生じ、訴えも増加することが 報告されている。従って見上げ姿勢で大型ディ スプレイを長時間注視することは、作業者の 梘機能, 筋骨格系に対する負担增加につながる 可能性がある。今回、大型ディスブレイ(1 10 インチ)を用いた監視simulation作業において2 種類の作業姿势 (仰角, 俯角)での生体諸機能の 変動を比較検討した。

\section{2. 方法}

\section{1 被験者}

被験者は、男子大学生 10 人(21.4 1.3 歳)。 8名は正視で、2名はコンタクトレンズ使用。

\section{2 タスク}

実験用に監視作業を simulateしたものを作成 した。画面上には20個の計器が表示されてい る。1分間に約10回の頻度で、どれかの計器の 針が警報域に侵入する。作業では、警報域に 入った計器をマウスでクリックしてリセット する。クリックする時以外は画面中央の円内 にカーソルを位置させるよう指示した。

\section{3 実験条件}

仰角条件の実験では、大型ディスプレイの 底部を床から $55 \mathrm{~cm}$ とし、画面中央部を見た ときの仰角が5度前後となるようにした。

俯角条件の実験では作業者, 机, 椅子, マウ スおよびキーボードを高さが調節可能なプラッ トホームに乗せ画面中央部を見たときの俯角 が15度になるようにした。両条件での実験環 境は以下の通りである。作業者とディスプレ イ間の距離； $400 \mathrm{~cm}$ 、水平視角；30度, 垂直視 角; 約20度、作業台水平面照度; $500 \mathrm{~lx}$ 、画面 鉛直面照度；250 lx

\section{4 検討項目}

眼と筋骨格系の症状は質問紙を用いた。各 質問項目への回答を全くない(0 点)から、かな り(4点)まで5段階で点数化した。視機能は赤外 線オートリフラクトメータ(Nidek)を用い、屈 折值, 近点屈折值, タークフォーカス, 調節応答 のずれ(Cq, Rq)およびステップ応答速度(調節 㗨張, 調節弛緩)を測定した。瞬き回数は垂直 方向のEOG(electrooculography)を記録し算出し た。心電図はCM5 の位置で記録。筋負担は、 作業中に僧帽筋と三角筋の表面筋電図を記録 し評価した。筋電図は、最大筋力発揮時の振 幅との比に直して(標準化)条件間の比較を行っ た。

自覚症状(眼, 筋骨格系), 視機能は作業前後 に評価した。瞬き,心電図および表面筋電図は 作業前安静記録(座位・開眼)を5分間行い、90 分間の作業中は連続で記録した。

\section{3. 結果}

\section{1 自覚症状}


仰角条件で"眼に異物感"の訴えが有意に増 加した。また"まぶしい", "ぽやけて見える" の訴えが仰角条件で増加傾向となった(図 1)。 筋骨格系の訴えでは、条件間の差はなかった。

\section{2 生理心理機能}

視機能では、 Rq (error of response to far target) のみ、作業後に有意に増加したが(図 2)、注視 角度の主効果は認められなかった。その他の 項目は、作業による変動, 注視角度の効果いず れも認められなかった。

瞬き回数(図 3)では注視角度の効果が有意傾 向であった $(\mathrm{P}<0.10)$ 。区間ごとの比較では9区 間中7区間で仰角条件での瞬き回数が有意に増 加または、増加傾向となった。

僧帽筋の表面筋電図では、注視角度の主効 果は認められなかった。

\section{3 パフォーマンス}

平均反応時間, 正クリック率のいずれにおい ても仰角, 俯角条件間の差違は認められなかっ た。

\section{4. 考案}

今回の結果より、大型ディスプレイを仰角 姿勢で長時間使用することは、作業者の眼の 訴え(特に乾燥症状)を増加させる可能性が示さ れた。ディスプレイの位置が高くなると、眼 球露出面積が増加"), 沃液分泌量は低下"2)する事 が報告されている。仰角条件で、"眼に異物感 ", "まぶしい"の訴えが増加したが、これらは dry eyeの自覚症状でもある。

仰角条件にて、瞬き回数が増加しているの は、眼球露出面積増加, 涙液蒸発量増加に対す る代償と考えられる。先行研究にて涙膜安定 性と瞬き回数との間の相関関係が報告されて いる3)。Patel ( ${ }^{3)}$ は、瞬きは涙膜を菲薄化や破 壊より守る働きがあると考察している。一方、 オートリフラクトメーターで測定した調節機 能には大きな変動は認めなかった。実験の視 距離が $400 \mathrm{~cm}$ と遠く調節機能への負荷があま り強くなかったのかもしれない。

僧帽筋, 三角筋の筋電図に注視角度の主効果 は認められなかった。キーボード入力に比べ、 マウスを用いたタスクの筋負荷があまり強く なかったこと、作業中の姿勢変化(体幹の後傾)
が筋負担を軽減する方向に働いたこと、など が可能性として考えられる。

以上より、従来型VDTと同様大型ディスプ レイにおいても、作業姿势を考慮し見上げ姿 勢の注視を少なくするワークステーションの 設計が重要と考えられた。

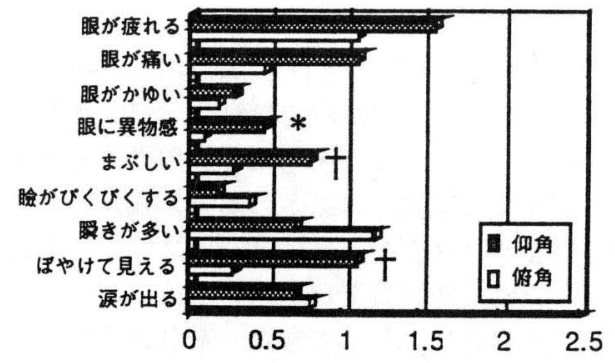

図 1 眼に関する訴えの作業前後のスコアの差(平均)

$(* ： \mathrm{P}<0.05$ vs 侑角, $+： \mathrm{P}<0.10$ vs 俯角)

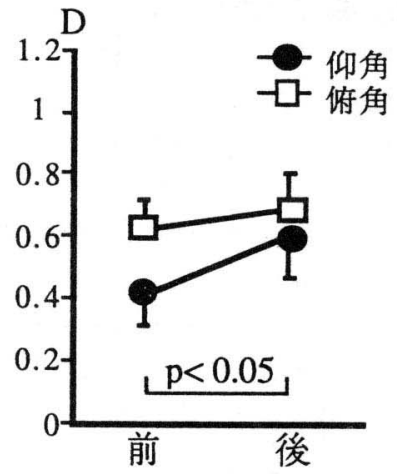

図 2 視機能 $R q$ (error of response to far target)

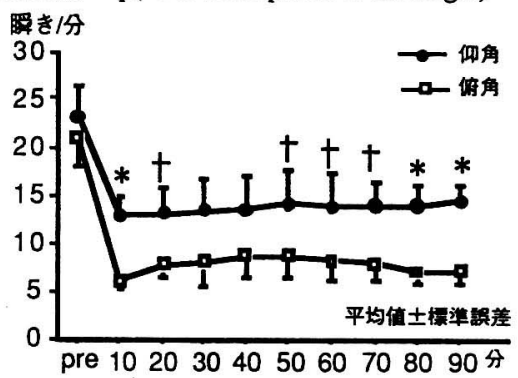

図 3 瞬き回数の変動

参考文献

$(*: P<0.05$ vs 俯角, $+: \mathrm{P}<0.10$ vs 俯角 $)$

1) Villanueva M.B.G. et al.: Adjustment of posture and viewing parameters of the eye to changes in the screen height of the visual display terminal, Ergonomics, 39(9), 933-45, 1996.

2) Abe S. et al.: Relationship between vertical gaze direction and tear volume, In Work with display unit 94, Grieco A. eds, Elsevier Scientific Publishers B.V., Amsterdam, pp 95-99, 1995.

3) Patel S. et al.: Effect of visual display unit use on blink rate and tear stability, Optometry and vision science, 68(11), 888-92, 1991. 